\title{
ANTICARDIOLIPIN ANTIBODIES IN COVID-19 - REPORT OF THREE CASES
}

\author{
Alina Dima ${ }^{1}$, Ruxandra Valentina Moroti ${ }^{2,3}$, Daniela Nicoleta Popescu ${ }^{1}$, Ioana Berza ${ }^{1}$, \\ Delia Adriana Pârvu', Bianca Dumitrescu ${ }^{1}$ \\ ${ }^{1}$ Colentina Clinical Hospital, Bucharest, Romania \\ 2"Matei Balș" INBI, Bucharest, Romania \\ ${ }^{3}$ "Carol Davila" University of Medicine and Pharmacy, Bucharest, Romania \\ ${ }^{4}$ Affidea Hiperdia Colentina Clinical Hospital, Bucharest, Romania \\ Corresponding author: Ruxandra Valentina Moroti \\ Infectious Disease Department, "Carol Davila" University of Medicine and Pharmacy; \\ Dionisie Lupu Street 37, RO-020022; Bucharest S2, Romania; \\ Email: ruxandra_moroti@yahoo.com.
}

\begin{abstract}
The severe acute respiratory syndrome coronavirus 2 (SARS-CoV-2) disease (COVID-19) is prone to thrombotic events with pathogenic mechanism that are still incompletely understood. Occurrence of antiphospholipid antibodies, especially anticardiolipin antibodies, was described in many viral infections and could be part of the chain in micro-thrombosis occurrence in COVID-19.

We herein present three cases of COVID-19 patients without any known immune background. For two of the patients, the laboratory tests show neither inflammatory syndrome, nor elevated D-dimer. Even if pauci-symptomatic patients, pulmonary involvement in as much as $10-25 \%$ was identified on chest computer tomography exam. In addition, a third patient, with more important pulmonary involvement (25-50\%), inflammatory response and elevated D-dimer levels is presented. None of the patients had prolonged activated partial-thromboplastin time. IgM and/or IgG anticardiolipin antibodies were found positives in all three cases.
\end{abstract}

Keywords: SARS-CoV-2, antiphospholipid syndrome, lupus coagulant inhibitor, thrombosis, pneumonia.

\section{Rezumat}

Sindromul respirator acut sever cauzat de infecția cu coronavirus (SARS-CoV-2) predispune la evenimente trombotice, prin mecanisme patogenice încă incomplet înțelese. Apariția anticorpilor antifosfolipidici, în special anticorpi anticardiolipinici, a fost descrisă în multe infecții virale și ar putea face parte din lanțul de evenimente care conduc la producerea microtrombozelor în COVID-19. 


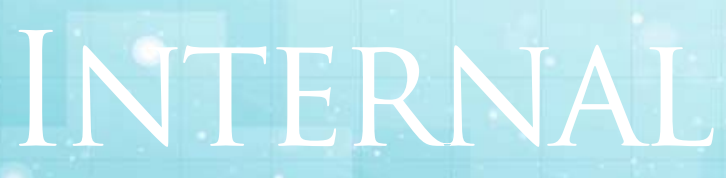

Clinical Cases.

Prezentăm trei cazuri de pacienți cu COVID-19, fără antecedente personale patologice cunoscute cu substrat imunitar. Pentru doi dintre pacienți, testele de laborator nu evidențiau nici sindrom inflamator, nici D-dimeri crescuți. Chiar dacă pacienții erau pauci-simptomatici, la tomografia computerizată toracică s-a constatat afectare pulmonară într-un procent de 1025\%. În plus, este prezentat un al treilea pacient, cu implicare pulmonară mai importantă (2550\%), răspuns inflamator și niveluri crescute ale D-dimerilor. La niciunul dintre pacienți nu s-a înregistrat creșterea timpului de tromboplastină parțială activat.

Anticorpii anticardiolipină IgM și / sau IgG au fost pozitivi în toate cele trei cazuri.

Cuvinte cheie: SARS-CoV-2, sindrom antifosfolipidic, inhibitor al coagulantului lupic, tromboză, pneumonie.

\section{Introduction}

First cases of highly infectious and contagious severe acute respiratory syndrome coronavirus 2 (SARS-CoV-2)/ coronavirus disease 2019 (COVID-19) occurred in Wuhan, Hubei Province of China in December $2019^{(1)}$. It determined an outbreak of viral pneumonia (COVID-19) declared pandemic by the World Health Organization in March $2020^{(2)}$.

The COVID-19 manifestations might encounter fever, muscle soreness, anorexia, sore throat, cough, nasal congestion, headache, ageusia, anosmia, diarrhea, nausea $^{(3)}$. The severe COVID-19 forms are characterized by breath shortening with polypnea (> 30 breaths/minute), low oxygen saturation $(<93 \%)$, more than $50 \%$ lung involvement on pulmonary computer tomography (CT), and possible multiple organ dysfunction ${ }^{(1)}$.

The inflammatory systemic response, as expressed by increased levels of interleukin6, C-reactive protein (CRP), ferritin or procalcitonin (PCT), might be important, going up to "cytokine storm" in severe COVID-19 cases $^{(1)}$. In critically ill patients, the cause of death was not triggered only by the pneumonia gravity and related inflammatory state, but also by the subsequently occurrence of coagulations abnormalities, micro thrombosis and pulmonary thromboembolism (PTE) in some $\operatorname{cases}^{(2)}$. Moreover, the elevated D-dimer were found to be associated with worse prognosis in COVID-19 ${ }^{(4)}$, but there is not enough data yet regarding the mechanisms or the independent value of the D-dimer ${ }^{(5)}$. One fifth of the COVID-19 patients have prolonged 
activated partial-thromboplastin time (aPTT) and in $91 \%$ of these lupus anticoagulant (LAC) is found ${ }^{(6)}$.

The antiphospholipid syndrome (APS) is defined by positive criteria antiphospholipid antibodies (aPL), namely LAC, IgM/ IgG anticardiolipin antibodies ( $\mathrm{aCL}$ ), and/or IgM/ IgG anti-beta 2 glycoproteins antibodies (aß2GPI) in patients with a history of thrombotic events (arterial/ venous) or pregnancy pathology ${ }^{(7)}$. There are also many other aPL described, besides the criteria ones, for which a definite clinical significance was still not established $^{(8)}$.

\section{Case reports}

At the beginning of the SARS-CoV-2 infection in Romania in April 2020, aPL were assessed in our department in COVID-19 patients without any known background of autoimmune diseases.

Therefore, we herein present first three COVID-19 patients for whom the aPL screening was positive. All patients were contact with first-degree family relative known with COVID-19. Also, in all three cases, the diagnosis was confirmed by real-time (RT) polymerase-chain-reaction (PCR) SARS-CoV2 using specimen derived from oropharyngeal swabs.

\section{Case 1}

62-year-old female, who complained for 3 days before admission of symptoms consisting in fever (not measured), anosmia, ageusia, headache, sporadic cough, and loss of appetite. The patient had been hypertensive, known with a history of cardiac ischemic disease, paroxysmal atrial fibrillation events, chronic B hepatitis, dyslipidemia, anxious syndrome, and spine post-traumatic surgery. She had chronic treatment with betablocker, diuretic, angiotensin-converting-enzyme (ACE) inhibitor, statin, new oral anticoagulants (NOAC) by apixaban, and anxiolytics. The physical examinations showed $33.5 \mathrm{~kg} / \mathrm{m}^{2}$ body mass index (BMI), $36^{\circ} \mathrm{C}$ body temperature (afebrile during hospitalization), $140 / 90 \mathrm{mmHg}$ blood pressure, 68/min heart frequency, and $97 \%$ oxygen saturation in room air.

Routine blood tests results showed neutropenia with lymphopenia (corrected on following controls), without inflammatory syndrome (during hospitalization). The Ddimer level was normal (lab results shown in Tables 1-3). Hepatitis C was negative. Regarding the aPL tested, the IgM aCL were positive, while IgG $\mathrm{aCL}$ and IgG aß2GPI negatives (we cannot determine in our laboratory IgM aß2GPI). Also, LAC search in this patient would not have been relevant considering the ongoing NOAC. The CT exam (approx. day 8 of disease) showed minimal pulmonary involvement $(<10 \%)$ but images suggestive for COVID-19 pneumonia (see Figure 1A, 1B). RT-PCR SARS-CoV-2 tests came two times negative after 24 days.

\section{Case 2}

A 63-year-old male patient, former athlete, hypertensive for the last 4 years, had dyslipidemia and history of lumbar surgery for L4-L5 disc hernia. The blood pressure was well controlled by long-term treatment with angiotensin-receptor blocker and diuretic, and hyperlipidemia by statin. The patient complained of asthenia for the last 5 days without any other symptoms. Physical examinations showed $B M I 33 \mathrm{~kg} / \mathrm{m}^{2}$, $150 / 85 \mathrm{mmHg}$ blood pressure, $36^{\circ} \mathrm{C}$ body temperature, $60 / \mathrm{min}$ heart rate, $96 \%$ oxygen saturation in air room. Laboratory results during hospitalization did not show increase 


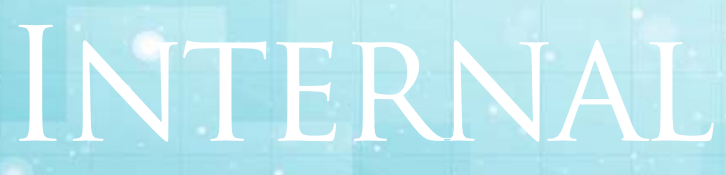

Clinical Cases.

of the inflammatory markers or of D-dimer (lab results shown in Table 1-3). Viral B and C hepatitis markers were negative. The C3, C4 complement levels were within limits, normal rheumatoid factor (RF) and negatives antinuclear antibodies (ANA). The IgG aCL were found positive (screening LAC positive, IgM aCL negative, IgG aßGPI negative). The electrocardiogram (ECG) showed bradycardia and grade 1 atrioventricular block.

The pulmonary CT (approx. day 7 of disease), despite the absence of any respiratory symptoms, showed ground-glass opacities suggestive of viral COVID-19 pneumonia in the both lung fields with moderate (10-25\%) involvement (Figure 2A, 2B). The patient was active, refractory to any invasive treatment, within limits systemic inflammation parameters and D-dimer, context in which a preventive anticoagulant treatment was not started. Taking in account the positive aPL, the possible procoagulant state associated to COVID-19 infection and the lack of contraindication, antiaggregant therapy by low level aspirin (100 mg daily) was added. RT-PCR SARS-CoV-2 test came twice negative after 28 days.

\section{Case 3}

A 69-year-old female patient, normal weight, hypertensive for the last months, without other antecedents, in treatment with betablocker and ACE inhibitor was hospitalized. The patient complained of asthenia and presented low grade fever for the last 3 days. Physical examinations showed $127 / 80 \mathrm{mmHg}$ blood pressure, $37.4^{\circ} \mathrm{C}$ body temperature, $84 / \mathrm{min}$ heart rate, $91 \%$ oxygen saturation in air room. Laboratory results during hospitalization showed increase of the inflammatory markers and D-dimer (lab results shown in Table 1-3) with progressive raise (max CRP $70.1 \mathrm{mg} / \mathrm{L}$; ferritin $1015 \mathrm{ng} / \mathrm{mL}$; D-dimer 0.94 $\mathrm{ug} / \mathrm{mL}$ ). Also, hepatic cytolysis and cholestasis was present (max TGP $85.1 \mathrm{UI} / \mathrm{L}$; GGT 206 UI/L).

Viral B and C hepatitis were absent. The C3, C4 complement levels were normal, ANA negatives, and normal RF. The IgG and IgM $\mathrm{aCL}$ were found positives (IgG aßGPI negative, screening LAC positive). The ECG was in normal limit. The CT exam (approx. day 6 of disease) showed extended groundglass opacities suggestive of COVID-19 pneumonia, approx. 25-50\% involvement (Figure 3A, 3B). Oxygen therapy (2 l/min) was added for 3 days. Also, preventive anticoagulation by low weight heparin for 7 days and switch with aspirin 100 mg daily when the patients refused injectable treatment. Evolution was favorable with progressive amelioration of the inflammatory syndrome and hepatic analysis. RT-PCR SARS-CoV-2 test was twice negative after 17 days. 


\begin{tabular}{|l|l|l|l|l|l|l|l|}
\hline & $\begin{array}{l}\text { Leucocytes } \\
\mathbf{X} / \boldsymbol{\mu L}\end{array}$ & $\begin{array}{l}\text { Neutrophils } \\
\mathbf{X} / \boldsymbol{\mu L}\end{array}$ & $\begin{array}{l}\text { Lympho- } \\
\mathbf{c y t e s} \\
\mathbf{X} / \boldsymbol{\mu L}\end{array}$ & $\begin{array}{l}\mathbf{C R P} \\
\mathbf{m g} / \mathbf{L}\end{array}$ & $\begin{array}{l}\mathbf{P C T} \\
\mathbf{n g} / \mathbf{m L}\end{array}$ & $\begin{array}{l}\text { Ferritin } \\
\mathbf{n g} / \mathbf{m l}\end{array}$ & $\begin{array}{l}\text { Fibrinogen } \\
\mathbf{m g} / \mathbf{d L}\end{array}$ \\
\hline $\begin{array}{l}\text { Normal } \\
\text { range }\end{array}$ & $4000-11000$ & $2000-8000$ & $\begin{array}{l}1500- \\
4500\end{array}$ & $0.0-5.0$ & $<0.05$ & $15-150$ & $\begin{array}{l}200.0- \\
400.0\end{array}$ \\
\hline Case 1 & 3440 & 1880 & 1120 & 2.15 & 0.04 & 70 & 401 \\
\hline Case 2 & 6500 & 3370 & 2150 & 1.35 & 0.05 & 381 & 475 \\
\hline Case 3 & 6510 & 5040 & 760 & 40.8 & 0.15 & 769 & 512 \\
\hline
\end{tabular}

Table 1. Laboratory parameters related to inflammation

Abbreviations: $C R P=C$-reactive protein; $P C T=$ procalcitonin

\begin{tabular}{|c|c|c|c|c|c|c|c|c|}
\hline & $\begin{array}{l}\text { Creatinine } \\
\text { mg/dL }\end{array}$ & $\begin{array}{l}\text { Uric } \\
\text { acid } \\
\text { mg/ dL }\end{array}$ & $\begin{array}{l}\text { ALT } \\
\text { UI/L }\end{array}$ & $\begin{array}{l}\text { AST } \\
\text { UIL }\end{array}$ & $\begin{array}{l}\text { GGT } \\
\text { UI/L }\end{array}$ & $\begin{array}{l}\text { TB } \\
\mathrm{mg} / \mathrm{dL}\end{array}$ & $\begin{array}{l}\text { CK } \\
\text { UI/L }\end{array}$ & $\begin{array}{l}\text { CK-MB } \\
\text { UI/L }\end{array}$ \\
\hline $\begin{array}{l}\text { Normal } \\
\text { range }\end{array}$ & $0.5-0.9$ & $2.4-5.7$ & $0.0-31.0$ & $\begin{array}{l}0.0- \\
32.0\end{array}$ & $\begin{array}{l}5.0- \\
36.0\end{array}$ & $0.0-0.3$ & $38-174$ & $7-25$ \\
\hline Case 1 & 0.74 & 5.8 & 9.5 & 22.6 & 51 & 0.21 & 76 & 19.7 \\
\hline Case 2 & 1.15 & 7.9 & 31.4 & 22.1 & 24 & 0.80 & 175 & 20.6 \\
\hline Case 3 & 0.86 & 3.9 & 52.3 & 45.0 & 64 & 0.36 & 82 & 11.3 \\
\hline
\end{tabular}

Table 2. General laboratory parameters

Abbreviations: $A L T=a l a n i n e$ aminotransferase; $A S T=$ aspartate aminotransferase; CK

=creatinine kinase; GGT =gamma-glutamyl transferase; TB =total bilirubin

\begin{tabular}{|l|l|l|l|l|l|l|l|l|l|}
\hline & $\begin{array}{l}\text { Thrombo- } \\
\text { cytes } \\
\text { X } \mathbf{1 0} / \mathbf{6 L}\end{array}$ & $\begin{array}{l}\text { MPV } \\
\mathbf{f L}\end{array}$ & $\begin{array}{l}\text { PT } \\
\mathbf{s e c}\end{array}$ & $\begin{array}{l}\text { aPTT } \\
\mathbf{s e c}\end{array}$ & $\begin{array}{l}\text { D-dimer } \\
\mathbf{\mu g} / \mathbf{m L}\end{array}$ & $\begin{array}{l}\text { Screeni } \\
\text { ng LAC }\end{array}$ & $\begin{array}{l}\text { aCL } \\
\text { IgM }\end{array}$ & $\begin{array}{l}\text { aCL } \\
\text { IgG }\end{array}$ & $\begin{array}{l}\text { aß2GPI } \\
\text { IgG }\end{array}$ \\
\hline $\begin{array}{l}\text { Normal } \\
\text { range }\end{array}$ & $\begin{array}{l}150000- \\
450000\end{array}$ & $\begin{array}{l}7.7- \\
10.4\end{array}$ & $\begin{array}{l}11.4- \\
14.1\end{array}$ & $\begin{array}{l}24- \\
37\end{array}$ & $0.0-0.5$ & $<1.2$ & $\begin{array}{l}0.0- \\
20.0\end{array}$ & $\begin{array}{l}0.0- \\
20.0\end{array}$ & $\begin{array}{l}0.0- \\
20.0\end{array}$ \\
\hline Case 1 & 196000 & 10.0 & 15.7 & 31.7 & 0.27 & - & 98.86 & 9.55 & 3.96 \\
\hline Case 2 & 181000 & 10.3 & 18.1 & 30.3 & 0.43 & 1.91 & 14.42 & 25.66 & 3.75 \\
\hline Case 3 & 119000 & 11.2 & 13.7 & 33.8 & 0.56 & 1.32 & 71.0 & 79.6 & 3.41 \\
\hline
\end{tabular}

Table 3. Laboratory parameters related to coagulation

Abbreviations: aCL =anti-cardiolipin antibodies; a $\beta$ GPI =anti-beta2-glycoprotein antibodies;

LAC =lupus anticoagulant; MPV =medium platelet volume; $P T=$ prothrombin time; aPPT

=activated partial thromboplastin time 


\section{INTERNAL}

\section{Clinical Cases}

\section{Discussions}

Coagulation abnormalities with tendency to prothrombotic status were reported in COVID-19 patients, without a clear understanding of all pathogenic pathways. In this context, increased D-dimer levels were found and were associated with severe COVID-19 prognosis ${ }^{(4)}$. On the contrary, the values of coagulation times and fibrinogen appears to be less influenced ${ }^{(9)}$. Regarding the coagulopathy development in the context of the viral infection with SARS-CoV-2, prophylaxis therapy with low molecular weight heparin was recommended when no contraindications $s^{(3)}$, but conclusive data on the usefulness of this approach are still missing $^{(4)}$.

In severe COVID-19 patients' death by PTE was reported and therefore in some cases contrast-enhanced CT is mandatory ${ }^{(2)}$. It is still unclear if the critically ill COVID-19 patients have a greater risk of venous thromboembolism when compared to other causes of severe pulmonary infections that might be also associated with D-dimer elevations ${ }^{(2)}$. The critically ill patients are most often immobile and so prophylactic anticoagulation should be considered during hospitalization in all patients when there are no contraindications ${ }^{(2)}$. There must also be distinguished between pulmonary thrombi and emboli as their pathogenesis is different ${ }^{(10)}$. In COVID-19 patients a discordance has been observed between the frequency of PTE occurrence when compared to much rarer deep vein thrombosis events $^{(10)}$. Moreover, arterial thrombosis was described, like infrarenal aorta or descending thoracic aorta ${ }^{(11)}$. The extension or gravity of viral COVID-19 pneumonia seems to not be related with the PTE occurrence $^{(12)}$.

Platelets are an important cellular component of hemostasis, but might be also integrated as inflammatory marker ${ }^{(13)}$ and modulator of the immune response ${ }^{(14)}$. Platelets number can be diminished in any acute viral infection by immune mediated pathways included. The platelets are also consumed during intravascular disseminated coagulation and/ or micro-/thrombi formation ${ }^{(13)}$. Thrombocytopenia was reported in 5 to $18 \%$ of the COVID-19 patients, being associated with disease prognosis $^{(4)}$ and the improvement of the platelets counts with subsequently clinical amelioration $^{(13)}$.

aPL positivity, especially aCL positivity, was described in many viral infections (like viral hepatitis, human immunodeficiency virus, Epstein-Barr virus, cytomegalovirus, parvovirus) $)^{(15)}$. The aPL positivity in these cases can be only transitory and without fully understood significance ${ }^{(16)}$. aPTT prolongation was described in $20 \%$ of COVID- 

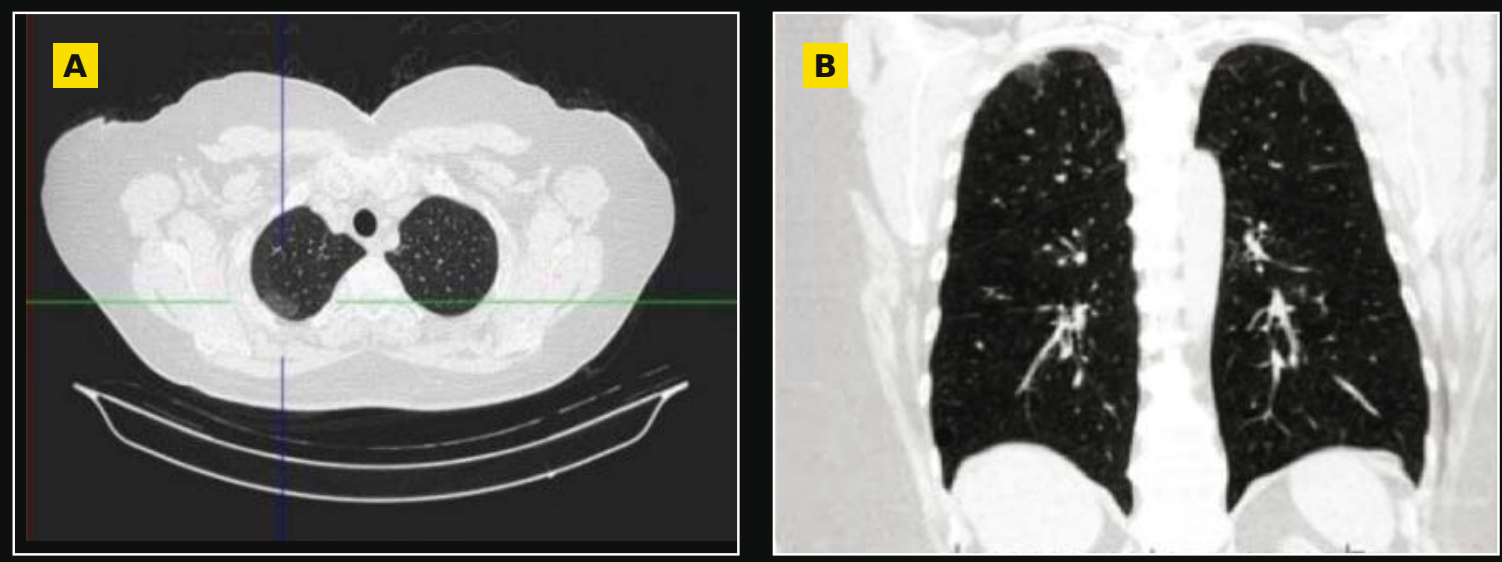

Figure 1. Chest computer tomography findings in case 1 ( $F$, 62years): less than $10 \%$ pulmonary involvement ( $A$ - transversal section; $B$ - frontal plane)
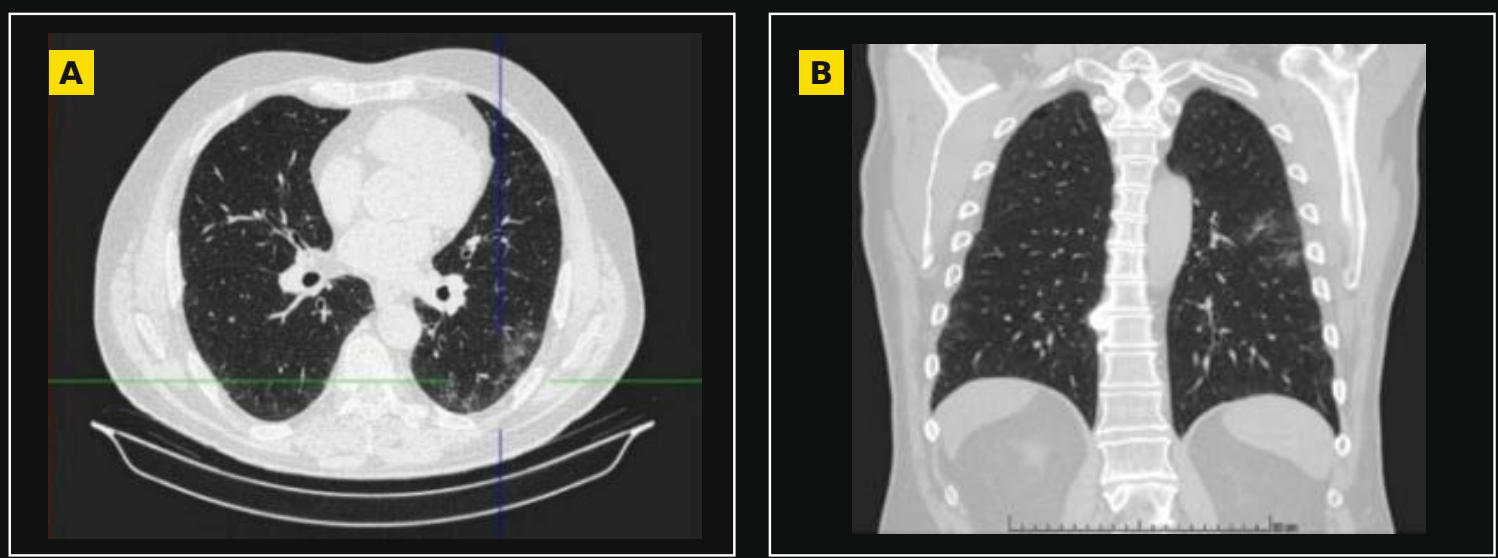

Figure 2. Chest computer tomography findings in case 2 (M, 63years): 10-25\% pulmonary involvement (A - transversal section; $B$ - frontal plane).
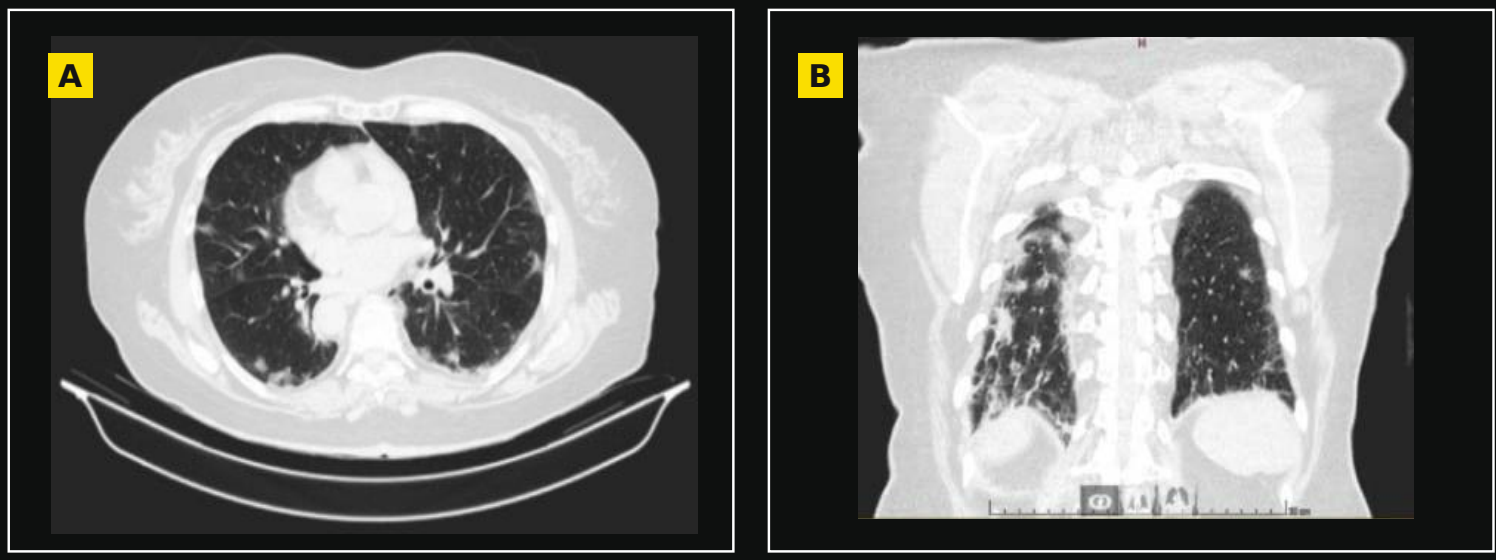

Figure 3. Chest computer tomography findings in case 3 (F, 69 years): 25-50\% pulmonary involvement (A - transversal section; $B$ - frontal plane) 


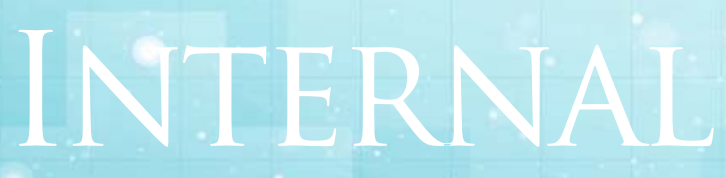

Clinical Cases.

19 patients and the great majority of these serums display LAC activity ${ }^{(6)}$, reason for which anticoagulation should not be stopped in COVID-19 patients with aPTT prolongation without a careful analysis ${ }^{(6)}$. aPL are one of the possible causes of aPTT prolongation and normal aPTT does not exclude LAC activity.

The treatment for APS is anticoagulation and NOAC proved to be inadequate. Even in the case of aPL positivity, the diagnosis of secondary APS cannot be sustained without the criteria aPL persistence for at least 12 weeks and in absence of clinical criteria ${ }^{(7)}$. Therefore, in our cases we continued the NOAC therapy in the first case, we added antiaggregant treatment in the second, and preventive anticoagulation followed by antiaggregating therapy in the last case.

Moreover, HCQ was shown to have thrombopreventive effects on long-term administration in primary APS by decreasing the aPL titers ${ }^{-17)}$. HCQ was recommended at the pandemic for COVID-19 therapy due to the antiviral effect observed in vitro at higher doses than those usually recommended in APS, but further the data for the HCQ usefulness in COVID-19 patients were controversial ${ }^{(18)}$ and then HCQ was completely withdrawn from the COVID-19 patients treatment.

In conclusion, we considered that it might be needed to search for $\mathrm{aPL}$ and to further consider antiaggregating and/ or anticoagulation in COVID-19. We presented here the first three cases from our department that developed positive aPL during the COVID-19.

Further, it is also important to find out if there is any persistence of the $\mathrm{APL}$; repeated search after 12 weeks is therefore needed. However, we do not have enough data to further emphasize on the frequency, pathogenic implications, or relevance over prognostic for aPL in COVID-19 patients. The data obtained at the pandemic beginning and presented here is only observations for future studies.

\section{Consent to participate and for data publication}

Oral and written informed consent for present/publish the data was obtained from the patients presented.

\section{Authors' contribution}

B.D., R.V.M., A.D., I.B., and D.N.P. discussed the research idea in April 2020; A.D. and B.D. drafted the first manuscript in May 2020. All authors were engaged in the management of the patients presented; All authors approved the final version of the manuscript.

\section{Abbreviations}

APS - antiphospholipid syndrome; aPTT activated partial-thromboplastin time; aCL anticardiolipin antibodies; $a \beta 2 G P I$ - anti- $\beta 2$ glycoprotein antibodies; aPL - antiphos- 
pholipid antibodies; BMI - body mass index; COVID-19 coronavirus disease 2019; CRP - Creactive protein; $C T$ - computer tomography; ECG - electrocardiogram; HCQ Hydroxychloroquine; LAC - Iupus anticoagulant; NOAC - new oral anticoagulant; $P C T$ - procalcitonin; PTE - pulmonary thromboembolism; RT-PCR - real-time polymerase-chain-reaction; SARS-CoV-2 severe acute respiratory syndrome coronavirus 2.

\section{References}

1. Liu F, Li L, Xu M, et al. Prognostic value of interleukin6, C-reactive protein, and procalcitonin in patients with COVID-19. J Clin Virol 2020;127:104370.

2. Scialpi M, Scialp S, Piscioli I, et al. Pulmonary thromboembolism in criticall ill COVID-19 patients. Int J Infect Dis 2020 Apr 24.

3. WHO. Clinical management of severe acute respiratory infection when novel coronavirus (nCoV) infection is suspected. 2020.

4. Violi F, Pastori D, Cangemi R, et al. Hypercoagulation and Antithrombotic Treatment in Coronavirus 2019: A New Challenge. Thromb Haemost Published Online First: 2020 Apr 29.

5. Gris J, Quéré I, Pérez-Martin A, et al. Uncertainties on the prognostic value of D-dimers in COVID-19 patients. J Thromb Haemost 2020 Apr 28.

6. Bowles L, Platton S, Yartey $N$, et al. Lupus Anticoagulant and Abnormal Coagulation Tests in Patients with Covid-19. N EnglJ Med 2020 May 5.

7. Miyakis S, Lockshin MD, Atsumi T, et al. International consensus statement on an update of the classification criteria for definite antiphospholipid syndrome (APS). J Thromb Haemost 2006;4:295-306.
8. Caraiola S, Jurcut, C, Dima A, et al. Antiphosphatidylethanolamine Antibodies and Deep Vein Thrombosis in Lupus Patients with Antiphospholipid Syndrome. Rev Rom Med Lab 2018;26:243-50.

9. Fan BE. Hematologic parameters in patients with COVID-19 infection. Am J Hematol 2020 Apr 27.

10. Cattaneo M, Bertinato EM, Birocchi S, et al. Pulmonary Embolism or Pulmonary Thrombosis in COVID-19? Is the Recommendation to Use High-Dose Heparin for Thromboprophylaxis Justified? Thromb Haemost 2020 Apr 29.

11. Vulliamy $P$, Jacob $S$, Davenport RA. Acute aorto-iliac and mesenteric arterial thromboses as presenting features of COVID-19. BrJ Haematol 2020 Apr 30.

12. Grillet $F$, Behr J, Calame $P$, et al. Acute Pulmonary Embolism Associated with COVID-19 Pneumonia Detected by Pulmonary CT Angiography. Radiology 2020; 201544.

13. Thachil J. What do monitoring platelet counts in COVID-19 teach us? J Thromb Haemost 2020:14879.

14. Albu DE, Copotoiu M, Szmuk P, et al. Platelets and Infections Course notes. Rev Română Med Lab 2018;26 (4): 497-502.

15. Mendoza-Pinto C, García-Carrasco M, Cervera R. Role of Infectious Diseases in the Antiphospholipid Syndrome (Including Its Catastrophic Variant). Curr Rheumatol Rep 2018;20(10):62.

16. MCNeil HP, Chesterman CN, Krilis SA. Immunology and Clinical Importance of Antiphospholipid Antibodies. Adv Immunol 1991;49:193-280.

17. Kravvariti E, Koutsogianni A, Samoli $E$, et al. The effect of hydroxychloroquine on thrombosis prevention and antiphospholipid antibody levels in primary antiphospholipid syndrome: A pilot open label randomized prospective study. Autoimmun Rev 2020;19(4):102491.18

18. Sarma $P$, Kaur $H$, Kumar $H$, et al. Virological and Clinical Cure in Covid-19 Patients Treated with Hydroxychloroquine: A Systematic Review and MetaAnalysis. J Med Virol 2020 Apr 16. 